\title{
EUROPEANIZATION AND \\ THE EMERGENCE OF A EUROPEAN SOCIETY
}

Juan Díez Medrano

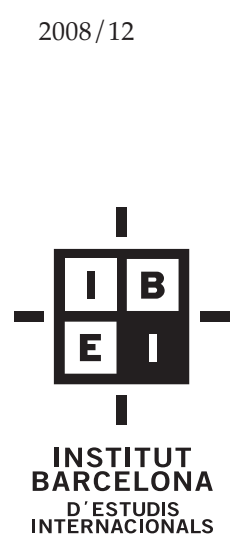

Juan Díez Medrano

Institut Barcelona d'Estudis Internacionals (IBEI) / Universitat de Barcelona. Research Program Coordinator "Networks and Institutions in a Global Society" at IBEI, and Professor of the University of Barcelona at the Dept. of Department of Sociological Theory, Philosophy of Law and Methodology for Social Sciences

jdiez@ibei.org / jdiezmedrano@ub.edu 
IBEI WORKING PAPERS

2008/12

Europeanization and the Emergence of a European Society

(C) Juan Díez Medrano

(C) IBEI, de esta edición

Edita: CIDOB edicions

Elisabets, 12

08001 Barcelona

Tel. 933026495

Fax. 933022118

E-mail: publicaciones@cidob.org

URL: www.cidob.org

Depósito legal: B-21.147-2006

ISSN:1886-2802

Imprime: Color Marfil, S.L.

Barcelona, January 2008 


\title{
EUROPEANIZATION AND THE EMERGENCE OF A EUROPEAN SOCIETY
}

\author{
Juan Díez Medrano
}

\begin{abstract}
This article examines the European integration process from a sociological perspective, where the main focus is the examination of the social consequences of the integration process. The European Union has advanced significantly in the economic, social, and political integration processes. This has resulted in a rapid Europeanization of behavior. There has hardly been any progress, however, toward the development of European social groups. This article examines the causes of this lag and concludes that it is highly unlikely that in the middle run there be significant progress toward the Europeanization of society.
\end{abstract}

Key words: European integration, Identity, Sociology. 


\section{Introduction}

The literature on European integration of the last fifty years has focused almost exclusively on the process of economic and political institutionalization. European society has figured in this literature only as a factor furthering or slowing down these developments. At most, scholars have paid attention to what people thought about the process, always with an eye to whether citizens gave their consent or not to elite decisions, or have attempted to explain why consent has become relevant to the European integration process. This neglect of societal developments in Europe reflects in part the compartmentalization of the social sciences and the fact that European integration has been a topic mainly addressed by political scientists, economists, and legal experts, that is those most directly concerned by the institutionalization process of what is today the European Union. The recent institutionalist turn in studies of European integration has meant, however, that concepts and analytical tools borrowed from sociology have become part of this literature. This borrowing has created bridges between political science and sociology and motivated sociologists themselves to enter the field of European integration. Some of them have made their own contributions to explaining the process of institutionalization, while others have started to explore topics neglected thus far by other disciplines. Thus, the 1990s witnessed the first comprehensive studies of European Union societies. Here I am mainly thinking of the work by Crouch, Rodríguez-Pose, Therborn, and Le Galès. The main novelty in these authors' studies is that they use Europe or the European Union rather than single states as the object of their descriptions of social structures or urban systems. What we still need, however, is an exploration of the ways in which the emerging institutional order in Europe has impacted on this society. That would be in my view the real object of a sociology of European integration. Recent work by people such as Berezin, Favell, Fligstein, Mérand, Guiraudon, Imig, Recchi, Tarrow, and Díez Medrano are motivated by this desire to bring European societies to the center of social scientific inquiry on the European Union. Katzenstein's recent book A World of Regions is also a rare exception in the IR literature for its concern on the impact of European integration and other regionalization processes on these regions' cultures. The timing of this interest in the societal impact of European integration is not random. The reason why it makes sense now and not in, let's say the 1960s, is that since 1986 what we now call the European Union has moved from being a customs union to becoming a single market with a common currency and institutions that cover a whole range of economic, social, and political policy areas. The new Europe Union has a tremendous impact on the European citizens' lives, whether they know it or not. The European Union is a multi-tiered polity, where government competences are distributed or shared by European, national, and subnational institutions. It is thus worth exploring what impact these dramatic institutional transformations have had on Europe's social structures rather than focus exclusively, as political scientists have done so far, on the impact of European social structures on the institutionalization process of the European Union.

I distinguish between two processes that presumably follow from the acceleration of European integration in the past 20 years. The first process is the 
Europeanization of national societies. There are several definitions of Europeanization in the literature, which are difficult to harmonize. Generally, they refer to the European Union's impact on domestic politics and national economies. In this chapter I depart from this definition, proposing one that makes it akin to a regional version of globalization. I define Europeanization of national societies as a widening of the scope of the national citizens' economic and political activities that directly or indirectly result from the economic and political institutions of the European Union. The term bears similarities with Katzenstein's concept of "Internationalization", but applies to the European scenario only. The second process I examine is the emergence of a European society proper, one that transcends national and subnational affiliations. Whereas the Europeanization of national societies refers back to a network conceptualization of the social structure, the emergence of a European society refers back to stratification and cultural conceptualizations of social structure. The focus here is on the emergence of European social groups, that is, transnational groups of European citizens whose consciousness and behavior denote solidarities that transcend national and subnational affiliations. My approach combines Marxist and Weberian conceptions of class. Like Marx, I distinguish between the concepts of class in itself and class for itself and focus on the identity/consciousness dimension of class. Like Weber, I distinguish between the concepts of class position and social class and focus on the interaction aspects of the latter: whereas class position is primarily defined in terms of objective opportunities in the market, social class involves the development of intense interaction between the members of a group (Bourdieu adds to this conceptualization of social class a "distinction" dimension, which refers to taste or what one can broadly define as consumption patterns). Identification with the group, intermarriage, joint political action, distinct consumption patterns, and social closure strategies are some of the dimensions one needs to explore when studying the emergence of a European society. Logically speaking, we would expect Europeanization to proceed faster than the emergence of a European society, since the former is a precondition of the latter. Indeed, Europeanization brings tourists, exchange students, migrant workers, readers, listeners, participants to Conferences, firms, and political claimants from different countries in contact. Without these contacts, the solidarities that constitute social groups could not develop.

This chapter, in the spirit of promoting a sociological research agenda on European integration, examines how far along we are in the development of these solidarities. Furthermore, relying on the literature on the development of nations and classes, I outline the main obstacles to the emergence of a European society. I argue that contrary to what a Deutschian approach would propose, the main obstacles to the emergence of a European society have less to do with the limited scope and intensity of intra-European transactions than with the politically decentralized character of the European Union and with the fact that the European Union has until now been spared a military confrontation with an external enemy. I conclude with two reflections: one on the prospects for a development of a European society and another related one on the current European Union crisis. 


\section{Europeanization}

Since 1986, the European Union has made tremendous strides toward the development of a single market, through the elimination of the numerous non-tariff barriers that existed to the free movement of goods, capital, and people. Today, one can say that there is a European Union single market for goods and a quasi-single market for capital and labor. I say a quasi-single market for capital because the nonharmonization of property rights across the European Union and informal barriers created by state governments makes some markets-i.e. the British-more open than others. A recent illustration of the remaining obstacles have been the decisions taken by the Spanish, Italian, and French governments, to prevent take-overs in the energy and banking sectors by other European corporations. It is a quasi-single market for labor because many informal obstacles exist to the movement of workers, as illustrated in Favell's ethnographic work on "free-movers" (2008). Among them, the lack of transparency in information on the availability of jobs, bureaucratic slowness in the recognition of qualification credentials in sectors where these are required, subtle forms of discrimination by national origin when hiring workers, informal forms of discrimination toward citizens from other EU member states when they look for housing or try to open bank accounts, misunderstanding of EU legislation by national bureaucracies, which leads to double taxation of those moving from one country to another or to the wrong administrative requirements, and lack of clarity with respect to the transportability of pension benefits. I would finally mention, the barriers to mobility created by clientelistic hiring practices in many European countries. Despite the shortcomings listed above one must admit that in the last twenty years there has been considerable momentum toward the creation of a single market. Parallel to this transformation, there has been a Europeanization of trade, investment, and labor markets. European Union member states trade much more with each other and depend more on trade with each other, not only in absolute terms, but also as a proportion of their total trade, than they did twenty years ago. Also, the number of European mergers and take-overs by other European Union corporations has increased quite substantially in the 1990s. This is reflected among others in an increase in the Europeanization of boards of directors. Kentor and Jank show for instance that between 1983 and 1998 the number of intra-European interlocking directorates per firm for European firms included in Fortune's Global 500 went from 0.18 to 0.51 . The authors focus on global interlocking and thus do not provide detailed information on the Europeanization of firms in specific countries. Nonetheless, they show that firms from the Netherlands, Belgium, and Germany are the most global, closely followed by French and British firms, in that order (Table 1). Finally, the 1990s have witnessed a significant increase in the number of EU qualified workers and professionals who choose to work in other European Union countries. Although trade, investment, and labor markets remain national, especially the latter, there is a clear Europeanization trend in all three areas.

The last twenty years have also witnessed the creation of the concept of European citizenship and the implementation of European Union policies aimed at providing tangible substance to this concept. Two policies have attracted popular attention. One of them has been the elimination of passport controls in the countries 
that signed the Schengen Treaty and the second one has been the promotion of student exchanges through the Erasmus and other similar programs. These two policies have decisively contributed to the Europeanization of the European Union citizens' travel and cultural experiences. The European Union has also indirectly contributed to this Europeanization of travel and cultural experience through liberalization measures in the air transportation industry, which have favored a significant lowering of travel costs around Europe, and financial support to the improvement of the European land transportation network.

Increased contact between producers, distributors, consumers, workers, students, across the European Union have provided a stimulus for the development of a growing trans-European network of voluntary civil associations (see 2008). This process has also been partly financially encouraged by the European Union, very especially through its Research and Regional funds, which have actively promoted the creation of European networks of professionals and researchers. This blooming of European associational life is another dimension of the Europeanization process that has taken place in the last twenty years.

Thus far, I have mainly focused on the Europeanization of member states' societies resulting from the European Union's policies to create a single market and to encourage cross-national contact between the citizens of its member states. In the last 20 years, the European Union has also considerably expanded its range of competences and the budgetary resources at its disposal. It has moved from being a mere customs union with a small budget almost entirely spent on the Common Agriculture Policy (CAP) to legislate on a wide variety of policy areas and to have a larger budget that can be used to fund a wide array of projects and activities. Furthermore, in the last twenty years the concept of the primacy of European Union law over national law has been firmly established. As the European Union has broadened its legislation and policy-making capacity, as its budget has increased and diversified, a growing number of social groups in the European Union states have developed stakes in the decisions of the European Union. It is no longer exclusively farmers. Workers, employers, consumers, researchers, residents in relatively poor regions, are increasingly affected. This significant increase in the political scope of the European Union has translated into a Europeanization of claims-making (see Imig and Tarrow, 2001). This Europeanization of claims-making means that an increasing number of citizens, interest groups, and social movements are addressing their claims to the European Union institutions (Table 2). It also means that an increasing number of groups, associations, social movements organizations, and lobbies are being formed, whose main goal is to impact on the European Union's decision-making process. The European Union itself has encouraged the formation of these network of associations, especially when they have a cross-national or European character.

In sum, there is a clear relationship between the strengthening of the European Union's economic and political institutions since the late 1980s and the Europeanization of the national societies, whether we think of exchanges, experiences, and political mobilization. But this Europeanization does not necessarily involve the emergence of a European society. When people exchange 
goods and invest capital in other European countries, when they sit in boards of directors in firms from different European countries, when they visit other European countries as tourists or exchange students, when they move to other European countries in order to work, when they join Europeanwide associations, when they address claims to the European Union institutions, they do not necessarily do it as members of an emergent European society. Nothing prevents them from doing it as Spaniards, French, English, or Czech citizens. Indeed, as I show and explain below, few do so as members of a European class or group, and while Europeanization is a first step toward the emergence of a European society, the latter will not necessarily follow from a further intensification of the Europeanization process. Further changes would be necessary for a new, European society, to emerge.

\section{A European Society?}

The sociological literature has assigned at least four meanings to the concept of social structure: 1) a system of institutions, 2) a system of stratification, with class as its main dimension, 3) a network configuration, and 4) a cultural system, with culture encompassing values, norms, beliefs, identities and taken-for-granted behavioral rules that differentially empower social actors. Seen from these perspectives, the study of the Europeanization process only corresponds to a weakties network conceptualization of the social structure. Both the stratification and the cultural conceptions of the social structure, however, demand that we focus on strong ties and on identity respectively when discussing the existence of a European society. This is particularly true if we consider both Marxist and Weberian contributions to the study of social structure. The European society that would interest Marx and Weber is not the one systematically examined by authors like Crouch, that is, a European society constructed on the basis of the aggregation of national statistics on occupational or sectoral distributions of the European labor force. It stands a level above this statistical construction. Both Marx and Weber see identity as a core constitutive element of a class. Thus, Marx distinguishes between a class "an sich" and a class "für sich", whereas Weber distinguishes between social position and social class, with the latter including a dense network of deep interaction that surely translates into group identity. Consequently, a Marxist and a Weberian understanding of class demand that we focus on three constitutive dimensions of a European social group in order to draw conclusions about the existence of a European society (Figure 1). One of them is the consciousness of being European, that is, identification with a society called Europe. A second one is the existence of strong ties between those who identify as European. In the study of the upper classes, intermarriage has generally been considered the ultimate indicator of such strong ties, not only because of the emotional element involved but also because it generally represents a form of capital merger, at least from the heirs perspective. Cold joint ownership of capital, that is, co-ownership without a deep emotional component, is another good indicator of strong ties. A third element in social groups as defined here is joint purpose and, more specifically, joint political action. Undoubtedly, a pre-condition for a social group to be appropriately described as European is that its members see themselves this way. 
The two behavioral elements, direct or marriage-mediated capital merger and joint political action, help to describe the strength of the European sense of membership, with joint political action expressing a greater degree of solidarity than joint membership in an European voluntary association, such as a European bowling club. A fourth element of social groups not so much defines them as generally follows from their existence. This is the development among its members of shared consumption practices as they compete for symbolic capital with other social groups.

It is easy to see how Europeanization is a pre-requisite for the emergence of European social groups. Europeanization means contact, direct or virtual, and without such contact it is difficult to see how people from different European countries would intermarry, merge capital in practices of co-ownership, or come to see themselves as Europeans. Europeanization also includes the creation of voluntary Europeanwide associations that with time have the potential to become so cohesive as to become the foundation for European politicized mobilization.

What evidence do we have to talk of a European society? What has been the impact of the political and economic institutional developments of the past few decades in the European Union on the emergence of a European society? Very little indeed, which is good for sociologists, for it means that there are ample opportunities for research. Fortunately, we have good information on the prevalence of a sense of identification with Europe among the population. This information, collected with some regularity through the Eurobarometer and other surveys provides conclusive evidence that the transformations of the European Union in the last twenty years and the Europeanization of national societies have had no impact whatsoever on the degree of identification with Europe by European citizens. The degree of identification with Europe has remained more or less constant through these years of European integration and of concomitant Europeanization (Table 3). While we can conclude that the Europeanization of economic and political behavior and of experience have not translated into a conmesurate emergence of a shared sense of identification with Europe, one should not dismiss the finding that about $57 \%$ of the respondents in the Eurobarometer 62.0, conducted in 2004 expressed some form of identification with Europe. The core of this group was formed by $10 \%$ who identified primarily as Europeans. The same survey asked them about how close respondents felt to Europe and $68 \%$ of them said that they felt close or very close. Since national identification varies across Europe and sometimes competes with subnational and even local identifications, we get a better sense of the prevalence of identification with Europe if we compare data from these surveys with data on national identification in plurinational countries such as Spain and Switzerland. ISSP data collected in 2003 for these two countries show that in Spain 97\% express some form of identification with Spain, with only $24 \%$ of them identifying as Only Spaniards or as More Spaniard than member of their region. In Switzerland, $84.4 \%$ express some form of identification as Swiss, with $52 \%$ of the population identifying as Only Swiss or as More Swiss than members of their region. Meanwhile, about $91 \%$ and $92 \%$ of the Spanish and Swiss citizens respectively express close or very close attachments to their country. 
The data just discussed show a vast contrast between levels of identification with and attachment to the European Union and levels of identification with and attachment to the state in even the most plurinational states in Europe. Nonetheless, the fact that more than half of Europeans express some form of identification with Europe, even if usually secondary to the national or regional identifications, is indicative of a proto-European society layered over national and subnational societies. Whether it actualizes as a full-fledged society or not remains to be seen. The $10 \%$ or so citizens who identify more with Europe than with their nation and who at the same time feel close or very close to the European Union would form the core of this society. Ten percent is probably the upper boundary of EU citizens whom one could call Europeans. The literature has shown that younger, more educated citizens, and the upper echelons of the salaried work force are more prone to identify as Europeans than the rest of the citizens. The contrasts, however, between different social categories of individuals are not spectacular. This is by itself an indication that the concept of identification with Europe is not very salient in people's minds. Still, all theoretical perspectives on the topic of identification expect the above mentioned groups to represent the forerunners of European society, just as the middle classes were the first ones to develop a sense of identification with the nation, back in the late $19^{\text {th }}$ century.

Do those who strongly identify with Europe constitute a social class or a social group in the strong sense meant by Weber? To answer this question we could investigate the prevalence of love partnerships between nationals of different EU members who identify primarily as European. Indeed, in the past researchers have focused on intermarriage as an indicator of national cohesion in multiethnic states such as Yugoslavia (Sekulic et al., 1994; Botev, 1994). Also, the intermarriage rate between members of different EU states interests us because intermarriage could to some extent contribute to the transcendence of local identifications and the development of a sense of belonging to Europe. Unfortunately, there are very few studies on intermarriage between Europeans. This reflects in part the fact that intermarriage rates depend to a large extent on the pool of marriageable nonnational Europeans in a particular national marriage market, which raises difficult methodological problems in comparative and longitudinal studies. Data for Spain for 2004 reveal that there were 209125 marriages that year, of which 179671 (86\%) were between Spaniards. There were also 8711 inter-European marriages or by nonSpaniard European co-nationals. Of those, 8282 marriages involved individuals from two different European countries and 6942 involved a Spaniard and a European from a different country. Only 429 marriages involved non-Spanish Europeans marrying a co-national (most likely, co-nationals marry in their country of origin). Meaningfully interpreting these data is extremely complex and beyond this chapter's scope. At the very least, however, is that geographic mobility makes intermarriage between Europeans possible. In the absence of studies on intermarriage we may thus examine what mobility data tell us about the development of a scenario where these marriages become more frequent.

Mobility rates were low but rising in the fifteen old members of the European Union. The accession of twelve new members has been followed by a new EastWest migration wave, which will certainly increase the opportunities for intermarriage between Europeans. The migration that interests us, however, is that 
of what Favell labels "free movers", that is high skilled workers whose motivations for moving are not exclusively economic and certainly not political. The mobility rates of this group of European citizens are particularly interesting because their sociodemographic characteristics are similar to those of the citizens who most frequently identify as Europeans. The problem is that mobility rates by freemovers are difficult to measure because many do not register as residents (see Favell, 2008). Survey data on mobility intentions offer an indication, however, of trends among the population. The data I present here come from Spain, a country where because of relatively low income per capita one would expect more people to seize on the opportunities created by the European single market. They reveal that among young people under 30 the percentage of those who say that it is likely or very likely has that they will work abroad in the future has increased from $5.4 \%$ to $8.9 \%$ between 1992 and 2006. For 2006 this would mean about half a million people ready to seize on the new work opportunities abroad. If we focus on what Favell calls "free movers", that is, highly educated individuals, the percentages are significantly higher. Survey data show that the percentage of university-educated people aged between 18 and 30 who say that it is likely or very likely that they will work abroad has increased from $14.7 \%$ in the $1992-1995$ period to $19 \%$ in the $2003-$ 2006 period $^{1}$. These time trends suggest that the single market has succeeded in somewhat motivating young Spaniards to contemplate working abroad. The changes are moderate and expectations will probably never materialize. But they show an upside turn that would in the long run translate into higher marriage rates among individuals from different European Union member states and thus contribute to the emergence of European social classes.

Data on co-ownership suggest that investment patterns follow national strategies rather than cross-national, European, ones. Recently, for instance, a researcher at the Universidad de Barcelona performed network analysis with ownership data for the companies with the largest capitalization in the biggest stock markets in the European Union (Rodríguez, 2006). The analysis showed that many of those companies had assets in large companies from other EU countries. Further analysis showed, however, that investment strategies tend to have a national or extra-EU character, with some Spanish top companies, for instance, investing in the same companies as top US companies and Italian top companies investing in the same European companies as other top Italian companies. The only evidence for the existence of something akin to a "European" cluster of companies coordinating their investment strategies were the investment patterns of a group of four German and Belgian companies in the financial sector. These data on investment patterns suggest that a European capitalist class is emerging in the densely populated and capital-rich areas at the intersection of Germany and the Low Countries. It is not surprising that it is precisely in this geographical area where one finds the largest percentages of citizens identifying themselves as Europeans. In Belgium and West Germany, about $17 \%$ and $16 \%$ of the citizens respectively identify primarily as European, compared with about $10 \%$ for the European Union as a whole (Figure 2). 
Another way of assessing how strongly people identify with Europe is through examination of political mobilization patterns. Joint political mobilization is revealing of the existence of a consciousness among people from different EU countries of sharing interests in common. Work by Imig and Tarrow demonstrates that cross-national solidarity at the EU level is still weak (2001). There has certainly been a process of Europeanization of mobilization, as farmers, fisherman and other occupational groups have began to address their grievances to European Union institutions. We have witnessed a slight increase in coordinated mobilization on the part of workers across Europe, with the latest example being protest against the planned Bolkenstein directive for the liberalization of the provision of services across the European Union. But as Imig points out, despite the simultaneous character of mobilization, despite the similarity in the tactics employed, many instances of coordinated mobilization simply reflect the juxtaposition of domestic national interests rather than European interests proper (Imig, 2002). The kinds of actors who mobilize in this fashion actually represent the citizens who least identify with Europe in the European Union, that is, farmers and workers.

The examination of the organization and activities of interest groups does not provide a glossier picture with respect to the development of a European society. I will first focus on employers. In dealing with the European Union, employers have followed different strategies: 1) formed or joined EU interest organizations, such as UNICE; 2) directly lobbied EU institutions; 3) lobbied on national institutions to promote their causes; 4) coalesce with other national, transnational, or EU interest organizations; 5) hired professional consultants to push their causes. Most business associations now combine national with EU strategies. Resulting from this there are plenty of national associations' liaison offices in Brussels. Furthermore, consultancies and EU law firms have mushroomed in Brussels. Even regional associations have offices in Brussels (e.g. Patronat Pro Europa). Almost all national associations in these countries belong to EU associations. Associations, such as UNICE, monitor EU political developments, provide information to their members, function as a liaison with other interest organizations, and represent their member interests vis à vis the Commission. They are hampered, however, by the diversity of interests within them (Eising, 2004). Consequently, lobbying through national associations, itself secondary to direct lobbying or to lobbying through national sectoral associations, remains much more significant than lobbying through European sectoral associations or through UNICE.

One can narrow this analysis by focusing on a large association in a pluralist setting such as Italy. This association is Confindustria. Confindustria represents some 257 sectoral and territorial business associations and about 111000 firms. European integration has translated into a greater focus by Confindustria on European issues. This is revealed in documents and press releases. Another impact of European integration has been in the association's organization. Rather than compete in Brussels, directly or indirectly through UNICE, with its own associations, also represented in Brussels, Confindustria took the leading position in Brussels to support and coordinate all activities of member associations on EU affairs. It also asserted its autonomy vis à vis Unice. This indicates that European integration leads to a Europeanization of lobbying strategies but not necessarily to a Europeanization of interest groups. In fact, in Italy itself, regional associations have tended to 
challenge Confindustria and lobby directly in Brussels through their liaison organizations (see Eising, 2004). I could go on and show that the same national divisions exist among employers exist among workers grouped around ETUC, that is, the European Trade Union Confederation.

It should be clear by now that it is still early to speak of European social groups in the very strong sense outlined above. If they are emerging, the place to find them is the core regions of the European Union and even if one finds them there they would not represent but a small fraction of the $10 \%$ of the population who primarily identify as Europeans. Given the emergent character of this "European" middle class, it might be useful to approach the topic of the development of a European society in a less ambitious way, one that would focus less on the existence of European classes "für sich" and more on what one could call a European middle class "an sich". This is what Favell asserts in his forthcoming book when he asks us to focus on the behavior of freemovers in order to determine the characteristics of this European middle class (2008). In fact, seizing up on the opportunities of the new single market and settling in cosmopolitan cities like Amsterdam, Brussels, or London is for him the defining trait of this new class. Once we abandon the level of consciousness and self-identification as European in order to define the new European social classes and focus on behavior we may as well move beyond Favell's stress on mobility and focus on other behavioral indicators signalling the emergence of European class fractions within national stratification systems. It may indeed be the case that national bourgeoisies are splitting into a local and European ones, distinguished by their consumer patterns and their outlook on life, with the willingness to move to another country being just one indicator, perhaps the most important one, of this emerging split. These European segments of the national bourgeoisies may first develop as imagined communities, before they start coming into contact, driven by the common taste, through travel, student exchanges, work, or residence abroad, and begin to coalesce into a European class "für sich". A sociological agenda on European integration would include the investigation of the extent to which this split between local and European segments of national bourgeoisies is indeed happening.

\section{Explanations}

How do we explain the sluggishness in the development of a European society relative to the rapid Europeanization of behavior and experience?

The few scholars who have discussed the topic use Deutsch's work as their inspiration. Transactionalism predicts that a common identity will result from the intensification of contact, communication, and transactions among Europeans (provided this intensification proceeds faster at the European than at the national or other subnational levels). While Europeanization is an essential precondition for the development of a European society, both theoretical considerations and empirical data question that it play the central role. In other words, it is unlikely that in the foreseeable future the Europeanization of economic and political behavior and of experiences (e.g. travel, studying) will lead to the emergence of social groups that one can call 
"European". From an empirical perspective, I have already shown that Europeanization in the past twenty years has had a negligeable impact on the proportion of citizens who identify themselves as European. In fact, data show that Swiss and Norwegians, both from countries outside the European Union, express the same level of identification with Europe as the average EU citizen. From a theoretical perspective, to solely rely on transactionalism means to disregard the voluminous literature on national identity formation over the past twenty-five years. This literature points out that national building was more a top-down process than a bottom-up one (Eg. Gellner, 1983, Weber, 1981; Breuilly, 1986; Hobsbawm, 1989). While discursive networks and other forms of interaction may have contributed to the development of an imagined community among the literate, it was institutions created by an expanding state in late nineteenth century and early twentieth century Europe that began to integrate the average man and woman in these national imagined communities. I am referring to institutions such as the school and the army. As Eugen Weber puts it, it was the universalization of primary education and of conscription that turned "peasants" into "Frenchmen" (1983). In the contemporary world, political messages transmitted by the media have become the main vehicle for the transmission of national identities.

Recently, scholars sensitive to the existence of hierarchically nested identities have complemented the top-down perspective pioneered by Weber. Thus, in 1992 Edward Lawler made a very powerful argument to the effect that people identify most with those units on which individuals depend the most for their security. Decentralization processes whether in industry or in polities do not enhance people's attachment to the broader identity; on the contrary, they strengthen the local or narrower identities around which the decentralization processes are built because they increase the individuals' dependence on the security provided by those narrower units. Finally, historians of Britain and of other countries have highlighted the decisive role played by wars in the development of negative forms of identity, that is identities based on that which differentiates a group from other groups rather than on that which unites its members. Cooley (1991), for instance, stresses the crucial role played by war with France in the $18^{\text {th }}$ and $19^{\text {th }}$ centuries in the formation of British identity.

When we focus on the role of political institutions, on the role of relative security provision, and on war as a nation-building mechanism we begin to understand why despite a dramatic intensification of transactions in the last couple of decades, there has been little change in the degree to which citizens identify with Europe. First of all, state and national political elites are still in direct or indirect control of the main socialization agencies. Education remains a national or regional competence and, consequently, the geography and history curriculum in most countries are still predominantly national ones. My examination of secondary school British, German, and Spanish history textbooks since the 1940s showed that this is indeed so and that when these textbooks concentrate on extra-national geographical areas these tend to be former colonies, as in Spain or Great Britain (2003). Furthermore, in many countries recent trends have gone in the direction of emphasizing subnational history or geography rather than European ones. True, a bottom-up process is under way, the Bologna process, toward homogenizing systems of higher education. This homogenization has to do, however, with the duration and credit requirements of the undergraduate and graduate curricula. 
Second of all, the media remain national media, which give privileged access to national political actors over European Union actors. Data from the Europub.com project show that there has been no change whatsoever in the presence of European Union actors as claimants in the 1990s (Table 4). This contrasts with the Europeanization in claims-making that took place in the same period, as national actors addressed the European Union with increasing frequency. In other words, the media increasingly report claims address to the EU but there has been no change in the frequency with which the media report claims made by European Union actors. The "nation-building" capacity of the European Union through the media has thus remained constant in the 1990s.

In sum, the main nation-building institutions in today's Europe, the school and the media, remain national and focused on the state and regional levels.

When we focus on the sources of material security for European Union citizens, we see that the state and, sometimes, the regions are still responsible for those. It is indeed the state and the regions which provide public education, unemployment benefits, pensions, health insurance, housing allowances, etc...The population in fact opposes the transfer of these functions to the European Union, thus preventing European institutions from seizing control over a major mechanism for the creation of a European identity ${ }^{2}$. The European Union has certainly increased its role in the provision of security to European citizens, mainly through the structural and cohesion funds. Research that Mabel Berezin and I have conducted on the role of distance in support for European integration demonstrates that these structural and cohesion funds are associated with strong support for European integration in Spain, Greece, Portugal, and Ireland (Berezin and Díez Medrano, forthcoming). In the 1990s, Ireland moved from being one of the poorest states in Europe to becoming one of the wealthiest. Simultaneously, its citizens moved from being among those opposing European integration the most to becoming enthusiastic supporters. Our analysis shows, however, that these fund transfers have no impact on the level of attachment to Europe, not even in Ireland. One could interpret these results as indicative that the funds are not generous enough to offset the sense of security that citizens derive from the state to which they belong. After all, in the best of cases, namely Spain, they have represented only a tiny percentage of the GDP.

The discussion above therefore suggests that the lack of development of a European group identity in the European Union is consistent with theoretical predictions and supports more the top-down approach to identity-formation than the bottom-up or transactionalist one. One could add to this that the entire European Union edifice conspires against the erosion of national identities. Although the role of the European Parliament in the process of European integration has dramatically increased in significance over the last fifteen years, the the Council of Ministers, which represents the state's interests, remains the most powerful institution. In fact, the recently signed-and not yet ratified-Treaty of Lisbon further stabilizes the role of 
states by allowing for greater control by national parliaments over the European Union's legislative process. Furthermore, most policies in the European Union follow a territorial principle. This applies as much to rules for the recruitment of civil servants in the European Union as to policies such as the structural and cohesion funds or research and development policies, where one of the main requirements for the acceptance of proposals is that they consist of networks of researchers from the different members of the European Union. While this approach contributes to equity in the allocation of European Union resources, it has the perverse effect of strengthening the salience of national identity. This is again a consistent finding in the literature on identities. Identifications bear a direct relation to the extent of their institutionalization in government policies. For instance, a decision to classify the population into ethnic or racial categories, regardless of how justified this decision is, contributes to increasing the salience of these categories as the focus of identifications.

Autonomous developments outside the institutional context of the European Union also contribute to the strengthening of national identity. Examples of Europeanization about which one reads in the literature, such as the Football Champions League or the Eurovision song festival, just to name two popular ones, rather than contribute to the development of a European group identity intensify national sentiment by pitting one state against each other; thus the insistence with which regions such as Catalonia demand to have a Catalan football team. Eurovision, the Football Eurocup are nothing but welcome examples of the civilization of war between European countries. Wars, however, have historically been a mechanism for the strengthening of the contenders' identities. Meanwhile, nothing hints toward the formation of European teams to compete in the Olympics, football competitions, or other types of contest. To my knowledge, the golf Ryder cup is the only instance where a European team has been created. Sports, probably the most popular form of entertainment and significant for the development of identities, remain organized as battles between national teams.

One should not create false expectations, however, about what needs to happen for a European group identity to develop. Sociological theory predicts that a stronger European Union, the attribution of welfare state competences to the European Union, and a more de-territorialized form of government would favor a shift of identifications from the states and regions to the European Union. The theories discussed here, however, are incomplete. The static character of Lawler's theory of nested identities prevents us from distinguishing between processes of decentralization and processes of centralization of rule. While there is strong evidence to the effect that decentralization erodes identification with the whole, the evidence that centralization of rule leads to greater identification with broader identities is more ambiguous, partly because of the resistance the process generates among the political units that lose sovereignty. Meanwhile, Eugen Weber's study of the state's role in the creation of national identities focuses on France, a state that had been successfully centralized during Napoleon's rule. The historical record shows, however, that nation-building processes have been relatively unsuccessful in states where subnational imagined communities had developed before the state-led nation-building processes began. Scotland and Catalonia are prime examples of the resilience of identities that endured despite their respective states relentless efforts. 
Many other subnational identities centered on culturally distinctive traits were actually invented just as states were implementing homogenizing and nationbuilding policies. In sum, if states, despite the extensive power they were able to garner, failed to erase pre-existing identities and replace them with stronger national identities, how can we expect that these national and subnational identities, much stronger than any known imagined community in nineteenth century Europe, would be superseded by a European identity? The European Union would need to offer much more to the citizens than they currently do for a durable shift in identities to take place and it would first have to persuade them to have a go at demonstrating how much it can offer. The context is not favorable. First of all, because the state elites themselves would have to authorize this. Second of all, because in the citizens' eyes the European Union's most recent achievement, the single currency, has not been the panacea that EU officials promised. Its immediate effect was rising prices across Europe and five years since its introduction the European economies remain sluggish. Third of all, neither the European Union's official pronouncements nor the content of the EU Constitution promise much in terms of a strengthening of the European welfare state. Many French citizens actually feared that the Constitution would open the door to more liberalization and this is why they voted No.

The Europe Union that is unfolding is not and will not be in the foreseeable future a European society in the strong sense. It will continue to Europeanize and a European middle class distinguished by its "taste" may develop, but popular identities will remain anchored at the national and subnational levels. Europe will remain a multitiered polity with a segmented social structure, corresponding to the national and sometimes subnational levels. If we compare this situation with that prevailing in late nineteenth-century European societies perhaps the most significant development we can expect is the gradual emergence of a cosmopolitan and European upper class that would join the European aristocracy in constituting an actual European social group. The European upper class is still, however, in its very early development stages, with subjective European identifications not yet complemented by strong cross-national social ties or expressed in European political mobilization.

Does the discussion have implications for the European integration process? Some commentators and scholars since the late 1980s have liked to explain every major crisis in the European integration process with reference to an insufficently developed sense of belonging to Europe among the population of the European Union. To systematically address this issue would be the topic of another essay (see Díez Medrano, forthcoming). I will simply raise a few considerations: First of all, survey research provides ample evidence to demonstrate that the degree of identification with Europe is only one factor among many explaining support for European integration. It can affect the kinds (structures) and intensity of conflict over the constitution of the European Union but hardly be the decisive factor (Hooghe and Marks, 2005). In fact, the citizens' level of education, age, occupation, political leanings, subjective economic appraisals, trust in EU institutions, subjective feelings of efficacy, and country of residence are all factors that impact on support for European integration net of their degree of identification with Europe. Secondly, European citizens consistently express support for transfers of sovereignty in key areas like foreign policy while political leaders behave as if they did not hear, undertaking instead steps toward integration in 
areas where support is much weaker, whether we speak of the single currency or enlargement to Central and Eastern Europe. Citizens of the European Union, despite their primary national-and even regional-identifications, generally like that their country is part of this project. In this sense, they behave more like Habermas's constitutional patriots than like old-fashioned nationalists. The citizens' occasional rejection of reform projects reflects the fact that, contrary to what happened before Maastricht, they are often asked to express their opinion in referenda and, also, the fact that their European project does not exactly coincide with that of their political leaders. The French and the Dutch, strong supporters of membership in the European Union and of European integration, were not voting against Europe; they were simply voting against a particular conception of Europe. This is the stuff of politics and not of "identity" politics.

Table 1. Number of Interlocking Directorates per Firm: Global 500, 1983 to 1998

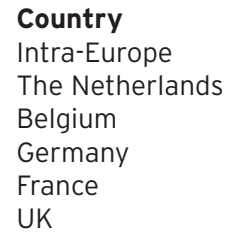

Source: Modified version of Table 3 in Kentor and Jang. 2004. A Growing Transnational Business Community.

Figure 1. Dimensions of European Social Groups

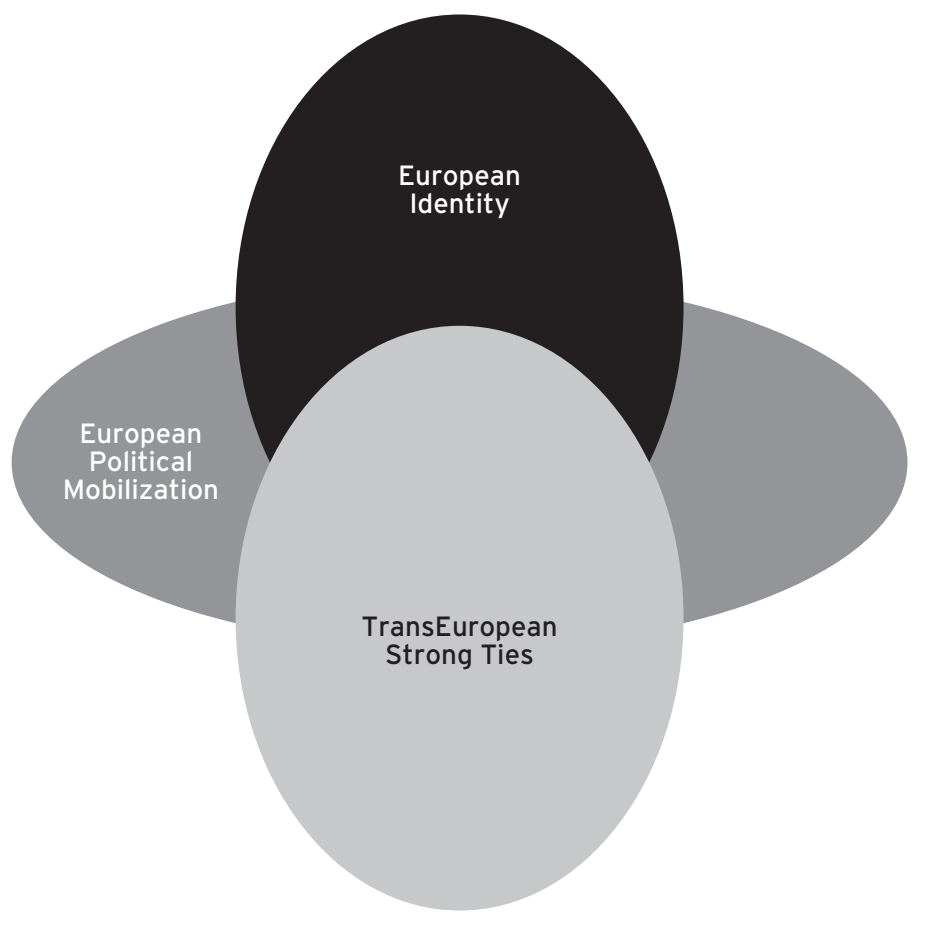


Table 2. Claims-making in national public spheres. Percentage of claims with a European-level adressee, by country and year.

$\begin{array}{lccccc} & \mathbf{1 9 9 0} & \mathbf{1 9 9 5} & \mathbf{2 0 0 0} & \mathbf{2 0 0 2} & \text { Average 1990-2002 } \\ \text { Germany } & 14 & 13 & 26 & 19 & 18 \\ \text { Switzerland } & 28 & 15 & 24 & 14 & 21 \\ \text { Spain } & 9 & 7 & 28 & 27 & 18 \\ \text { Italy } & 8 & 10 & 26 & 15 & 17 \\ \text { United Kingdom } & 11 & 15 & 18 & 37 & 15 \\ \text { France } & 19 & 32 & 34 & 25 & 31 \\ \text { Netherlands } & 10 & 17 & 28 & 23 & 20 \\ \text { Seven-country average } & 14 & 16 & 26 & & 20\end{array}$

Source: Ruud Koopmans, 2004. "Integrated Report: Analysis of Political Claims in European Print Media", in The Transformation of Political Mobilization and Communication in European Public Spheres, Project Europub.com, funded by the Vth Framework Programme of the European Commission, Contract Number: HPSE-CT2000-00046

Table 3. Trends in Relative Identification (1992-2004)

\begin{tabular}{|c|c|c|c|c|}
\hline & 1992 & 1996 & 2000 & 2004 \\
\hline Nationality Only & 40.0 & 53.3 & 39.5 & 41.4 \\
\hline Nationality and European & 47.3 & 35.4 & 47.5 & 46.9 \\
\hline European and Nationality & 6.1 & 5.5 & 6.3 & 6.9 \\
\hline Only European & 3.2 & 3.5 & 3.4 & 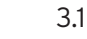 \\
\hline DK & 3.4 & 2.3 & 3.2 & 1. \\
\hline
\end{tabular}

Source: Eurobarometer (European Commission)

Figure 2. Strong Multinational Capital Owners
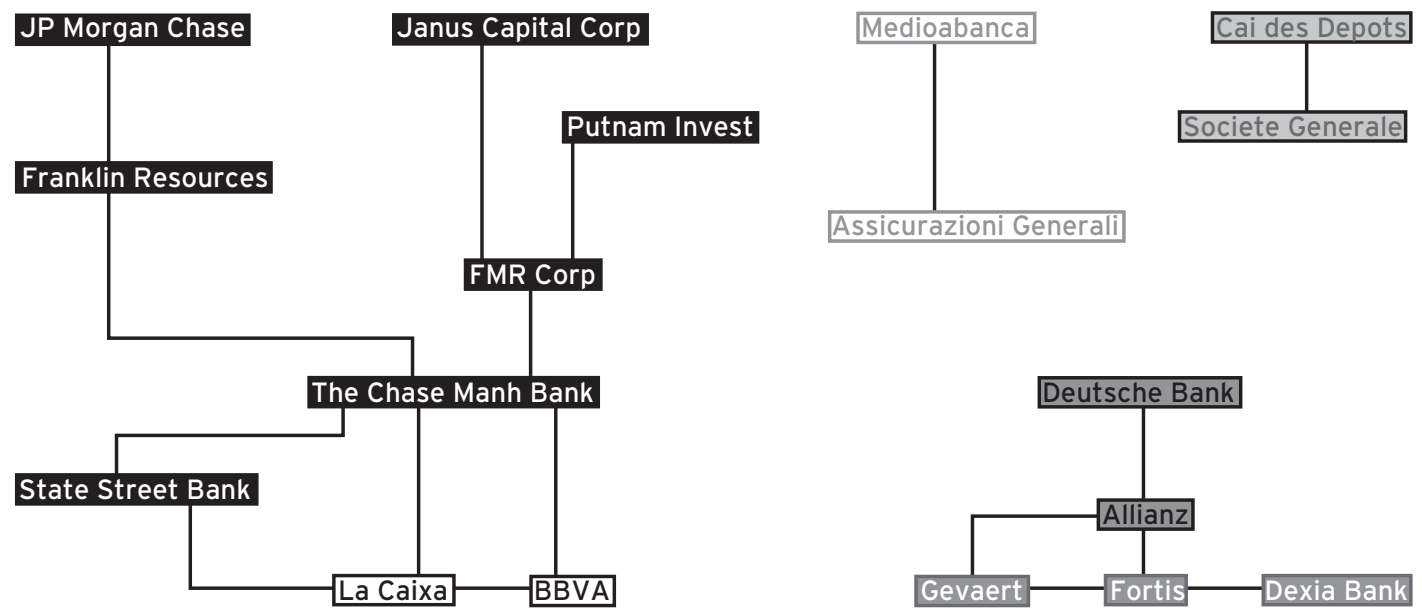

Spain US Italy France Germany Belgium

Source: Josep A. Rodríguez. 2006 
Table 4. Claims-making in national public spheres. Percentage of claims with a European-level actor, by country and year. ${ }^{3}$

$\begin{array}{lccccc} & \mathbf{1 9 9 0} & \mathbf{1 9 9 5} & \mathbf{2 0 0 0} & \mathbf{2 0 0 2} & \text { Average 1990-2002 } \\ \text { Germany } & 8 & 8 & 10 & 13 & 10 \\ \text { Switzerland } & 11 & 7 & 9 & 12 & 10 \\ \text { Spain } & 15 & 12 & 16 & 19 & 16 \\ \text { Italy } & 7 & 18 & 14 & 17 & 14 \\ \text { United Kingdom } & 5 & 6 & 7 & 8 & 7 \\ \text { France } & 11 & 15 & 11 & 11 & 13 \\ \text { Netherlands } & 6 & 5 & 10 & 13 & 8 \\ \text { Seven-country average } & 9 & 10 & 11 & & 11\end{array}$

Source: Ruud Koopmans, 2004. "Integrated Report: Analysis of Political Claims in European Print Media", in The Transformation of Political Mobilization and Communication in European Public Spheres, Project Europub.com, funded by the Vth Framework Programme of the European Commission, Contract Number: HPSE-CT2000-00046

\section{References}

Berezin, Mabel and Juan Díez Medrano. 2008. Distance Matters: Place, Political Legitimacy, and Popular Support for European Integration. Comparative European Politics. In Press.

Breuilly, John. 1993. Nationalism and the State. Chicago: University of Chicago Press.

Checkel, Jeffrey. 1998. Social Construction and Integration. Journal of European Public Policy, 6 (4): 545560.

Colley, Linda. 1992. Britons: Forging the Nation: 1707-1837. New Haven: Yale University Press.

Constantelos, J. 2004. The Europeanization of Interest Group Politics in Italy: Business Associations in Rome and the Regions. Journal of European Public Policy, 11 (6): 1020-1040.

Crouch, Colin. 2000. Social Change in Western Europe. Oxford: Oxford University Press.

Díez Medrano, Juan. 2003. Framing Europe. Princeton, NJ: Princeton University Press.

Díez Medrano, Juan. 2008. The public sphere and Europe's political identity. In Checkel, Jeffrey T. and Peter J. Katzenstein (eds.). The Politics of European Identity. Cambridge: Cambridge University Press.

Favell, Adrian. 2008. Eurostars and Eurocities. Oxford: Blackwell. In Press.

Fligstein, Neil. 2008. Euroclash. Oxford: Oxford University Press. In Press.

Fligstein, Neil and Iona Mara-Drita. 1996. How to Make a Market: Reflections on the attempt to create a Single Market in the European Union. American Journal of Sociology, 102: 1-33.

Fligstein, Neil and Frédéric Mérand. 2002. Globalization or Europeanization? Evidence on the European Economy since 1980. Acta Sociologica, 45 (1): 7-22.

Fligstein, Neil and Alec Stone Sweet. 2002. Constructing Polities and Markets: An Institutionalist Account of European Integration. American Journal of Sociology, 107 (5): 1206-1243.

Gabel, Matthew. 1998. Interests and Integration. Ann Arbor: University of Michigan Press.

Gellner, Ernest. 1983. Nations and Nationalism. Ithaca: Cornell University Press.

Guiraudon, Virginie. 2000. Sociologie de I' Europe: Mobilisations, elites, et configurations constitutionelles. Culture et conflits 38/39.

Hooghe, Lisbet. 2003. Europe Divided? Elites vs. Public Opinion on European Integration. European Union Politics, 4 (3): 281-305. 
Hooghe, Lisbet and Gary Marks. 2005. Calculation, Community, and Cues: Public Opinion on European Integration. European Union Politics, 6 (4): 419-443.

Imig, Douglass. 2004. Contestation on the Streets: European Protest and the Emerging Euro-polity. Comparative Political Studies, 35 (8): 914-933.

Imig, Douglass and Sidney Tarrow (eds.). 2001. Contentious Europeans: Protest and Politics in an Emerging Polity. Lanham: Rowman, and Littlefield.

Jachtenfuchs, Markus. 2002. Die Konstruction Europas: Verfassungsideen und Institutionelle Entwicklung. Baden-Baden: Nomos.

Katzenstein, Peter. 2005. A World of Regions. Ithaca: Cornell University Press.

Kentor, Jeffery and Jank, Young Suk. 2004. Yes There is a (Growing) Transnational Business Community: A Study in Interlocking Directorates 1983-98. International Sociology, 19 (3): $355-$ 368.

Lawler, Edward. 1992. Affective Attachments to Nested Groups: A Choice-Process Theory. American Sociological Review, 57, (3): 327-340.

Le Galès, Patrick. 2002. European Cities: Social Conflicts and Governance. Oxford: Oxford University Press.

Mann, Michael. 1993. The Sources of Social Power, Vol. 2. Cambridge: Cambridge University Press.

Meehan, Elizabeth. 2000. Citizenship and the European Union. Discussion Paper presented at the Zentrum für Europäische Integrationsforschung, Rheinische Friedrich Wilhelms-Universität Bonn.

Mérand, Frédéric. 2006. Social Representations in the European Security and Defense Policy. Cooperation and Conflict, 41 (2).

Moravcsik, Andrew. 1998. The Choice for Europe: Social Purpose and State Power from Messina to Maastricht. Ithaca: Cornell University Press.

Peixoto, J. 2001. Migration and Policies in the European Union: High-skilled Mobility, Free Movement of Labor and the Recognition of Diplomas. International Migration, 39 (1): 33-61.

Pierson, Paul. 1996. The Path to European Integration: A Historical Institutionalist Perspective. Comparative Political Studies, 29 (2): 123-163.

Rodríguez, Josep, Julián Cárdenas and Christian Oltra. 2005. Redes de Poder Económico en Europa. Working Papers EPP-LEA, 01: 2-45.

Rodríguez Pose, Andrés. 2002. The European Union: Economy, Society, and Polity. Oxford: Oxford University Press.

Rosamond, Ben. 2000. Theorizing the New Europe. London: Palgrave.

Salt, John. 1992. Migration Processes among the Highly Skilled in Europe. International Migration Review, 26 (2): 484-505.

Taylor, G. and A. Mathers. 2004. The European Trade Union Confederation at the Crossroads of Change? Traversing the Variable Geometry of European Trade Unionism. European Journal of Industrial Relations, 10 (3): 267-285.

Weber, Eugen. 1983. Peasants into Frenchmen. Berkeley: University of California Press. 